
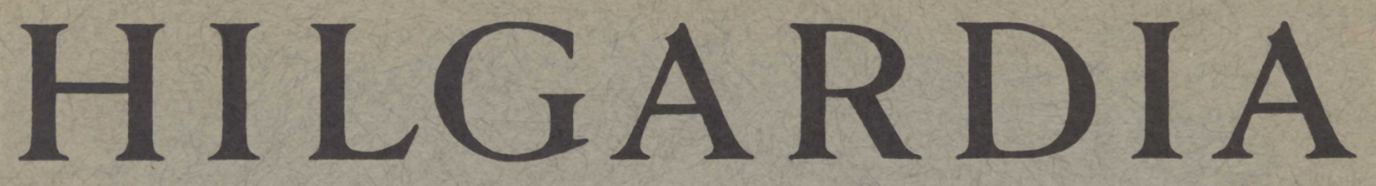

A Journal of Agricultural Science Published by the California Agricultural Experiment Station

\title{
OLIVE LEAF SPOT \\ AND ITS CONTROL WITH FUNGICIDES
}

E. E. WILSON and H. N. MILLER

UNIVERSITY OF CALIFORNIA - BERKELEY, CALIFORNIA 


\section{In Brief}

Olive leaf spot, caused by the fungus Cycloconium oleaginum Cast., has recently been prevalent in California. The first symptoms are inconspicuous sooty blotches on the leaf blade. As these enlarge, the rest of the leaf turns yellow. Severe defoliation follows leaf infection. In some orchards 10 to 20 per cent of the fruiting twigs died as a result of defoliation.

The fungus was isolated by transferring single ungerminated conidia to a solid medium. It proved to be extremely slow-growing. Only three of many isolates produced conidia in culture. Conidia germinated and mycelium grew between $9^{\circ}$ and $30^{\circ} \mathrm{C}$, the optimum being $16^{\circ}$ to $20^{\circ}$.

New lesions developed in the fall one season in central California, but not until late January and February in three other seasons. Affected leaves became yellow and fell during May and early June.

Lesions on leaves that remained in the tree seem to be the chief if not the only source of inoculum. These bore numerous conidia in spring but few during the summer. In autumn the fungus grew from the margins of such lesions into adjacent leaf tissue and produced conidia; thus a supply of inoculum was insured at a time when moisture conditions were favorable to infection. The spores seem to be spread by rain more than by air currents.

Bordeaux mixture (8-8-100 or 10-10-100) applied in fall or early winter effectively prevented leaf infection in three out of four seasons. Later applications gave less satisfactory control. For two seasons one treatment of 8-8-100 bordeaux proved less efficacious than two treatments. In the next two seasons, however, one November treatment of 10-10-100 bordeaux gave adequate protection. On the whole, proper timing of the bordeaux treatment seemed more important than renewing the fungicide deposit.

Ferric dimet hyl ditbiocarbamate and zinc dimetbyl ditbiocarbamate sprays containing an oil supplement ("sticker") reduced infection materially but not so effectively as bordeaux.

Yellow cuprous oxide in a two-treatment program reduced infection satisfactorily but injured the leaves.

Lime-sulfur ( 3 per cent) controlled leaf spot as effectively as 10-10-100 bordeaux.

Persistent effects of treatments were sometimes noted. In several orchards trees sprayed with bordeaux or lime-sulfur in only one season bore less leaf spot at the end of the next season than did unsprayed trees. 


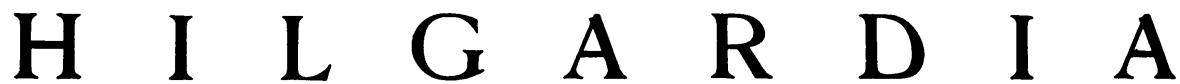

A Journal of Agricultural Science Published by

the California Agricultural Experiment Station

\section{OLIVE LEAF SPOT}

\section{AND ITS CONTROL WITH FUNGICIDES}

\section{E. E. WILSON ${ }^{2}$ and H. N. MILLER ${ }^{3}$}

\section{INTRODUCTION}

REPEATED OUTBREAKs of the leaf spot disease of olives (Olea europaea L.) caused by the fungus Cycloconium oleaginum Cast., have occurred in California for the past seven or eight years. This disease is well known in Mediterranean countries and has received the attention of plant pathologists there since the middle of the last century.

Although known in California for over fifty years, olive leaf spot received little attention until the recent outbreaks. In 1941 I. J. Condit ${ }^{4}$ and the late W. T. Horne, of the University of California Citrus Experiment Station at Riverside, began observations on the disease at Fall Brook, San Diego County, and in 1942 conducted certain spray tests. Condit and Horne's data (not published) indicate that a material reduction in infection followed applications of bordeaux sprays.

In January, 1944, we began fungicidal tests and observations on disease development at Fair Oaks, Sacramento County. The trials were conducted at this location until 1946, when the work was transferred to an orchard near Orland, Glenn County. The results of the observations and tests are presented herein.

\section{THE DISEASE}

Common Names. The disease has been called "bird's eye spot," "leaf spot," "peacock spot," and "Cycloconium leaf spot," the last name probably appearing most frequently in the literature.

Symptoms. Although symptoms most often occur on the leaf blade, they are sometimes found on leaf petiole, fruit, and fruit stem (Petri, 1913; Bernès, 1923). Condit and Horne observed lesions on fruit and fruit stems in San

\footnotetext{
${ }^{1}$ Received for publication September 10, 1948.

${ }^{2}$ Professor of Plant Pathology and Plant Pathologist in the Experiment Station.

${ }^{3}$ Research Assistant in Plant Pathology.

4 The writer is indebted to Dr. Condit for permission to cite certain information obtained by Professor Horne and him.
} 
Diego County, but we observed no such symptoms in central California. Petri (1913) reports lesions on both surfaces of the leaf, but we found them only on the upper surface.

Lesions on the leaf, at first inconspicuous sooty blotches (fig. 1, $A$ ), later develop into muddy green to almost black circular spots 2 to $10 \mathrm{~mm}$ in diameter. A faint yellow halo sometimes occurs in the leaf tissues around the spot. As the lesions expand, the rest of the leaf blade becomes yellow, and the leaf falls from the tree. The dark green to black spots on the yellow background of the leaf blade (fig. 1, B) are thought by some to resemble the spots on a peacock's tail, hence the name "peacock spot" (Bioletti and Colby, 1899).

Lesions are notably more abundant on foliage in the lower parts of the trees, many of the twigs in these parts becoming completely defoliated. The twigs frequently die from the effects of defoliation.

Less severely infected leaves which remain in the tree bear lesions that often are inconspicuous circular spots (fig. 1, $C$ ) with grayish surfaces. In late October and November, such spots increase in size (fig. 1, D) and may double their diameters within a few weeks' time. This expansion of old lesions, as shown later, is an important phase in the life cycle of the fungus.

Host Relations. The edible olive, Olea europaea, is the principal host of the fungus. Species of Phillyrea in Mediterranean countries are attacked by a fungus which has been designated (Nicolas and Aggéry, 1928) Cycloconium oleaginum var. phillyrea (Desm.) Nic. and Agg.

In France, most olive varieties are attacked, some being more severely affected than others (Foëx, 1924). The varieties Amellau, Rouget, and Verdale are listed as particularly susceptible (Boyer, 1891). In South Africa the Mission and Oblizia varieties are reported (Gorter, 1943) to be susceptible, Sevillano and Manzanillo moderately resistant, and Leccinia and Nevadillo Blanco highly resistant.

Of the principal olive varieties in California, the Mission was most commonly affected and the Manzanillo occasionally. Only a few inconspicuous lesions were found on the Sevillano, Barouni, Ascolano, and Nevadillo varieties. Among commercially less important varieties on the Experiment Station grounds at Davis, Cucco, Pendulina, Macrocarpa, and Polymorpha were found with varying amounts of leaf spot, whereas Otro-violacea, Rubra, and Columbello were little affected.

Geographical Distribution. Olive leaf spot has been reported from the following continents and countries :

Europe: France (Castagne, 1845), Spain (Navarro and Noriega, 1909), Portugal (Moniz da Maia, 1924), Italy (Brizi, 1894), the Dalmatian coast of what is now Yugoslavia (Guozdenovic, 1901), Cyprus (Nattrass, 1935), and Greece (Anagnostopoulos, 1937).

Africa: Eritrea (Canonaco, 1936), Tunis (Zacharewicz, 1903), Morocco (Miège, 1922), and the Union of South Africa (Gorter, 1943).

North America: United States (California) (Hayne, 1893).

South America: Chile (Anonymous, 1941).

Economic Importance. Leaf spot is marked by serious outbreaks at infrequent intervals. Although no estimates of losses from its effects are found in the literature, the damage done is of sufficient importance in Italy (Giulivo, 1927), Spain (Anonymous, 1932), France (Foëx, 1924), and South Africa

\footnotetext{
${ }^{5}$ No attempt was made to determine when the disease was first reported from the countries mentioned.
} 

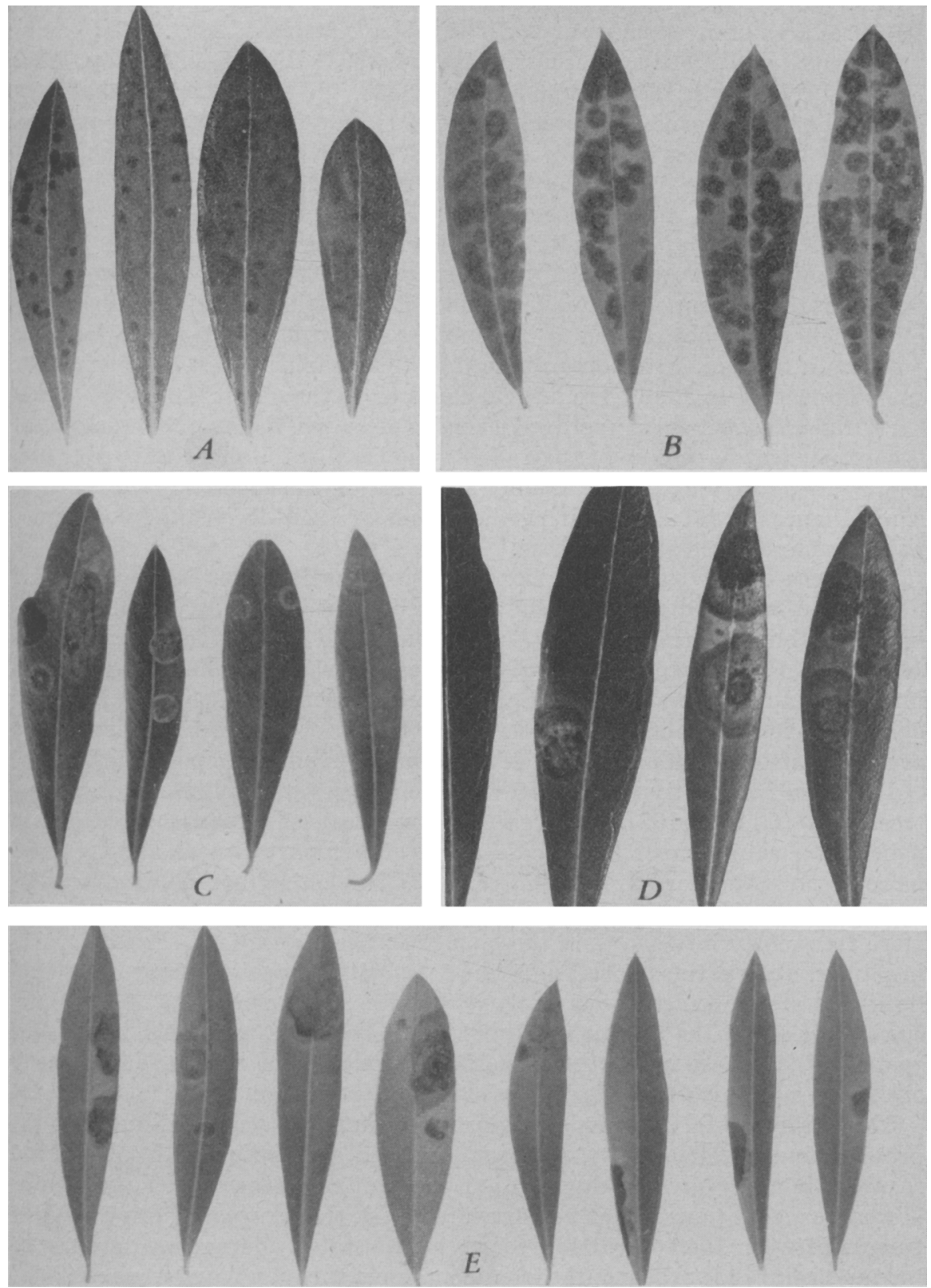

Fig. 1. $A$, New lesions shortly after becoming visible in late winter. $B$, Severely infected leaves after lesions have increased in size in spring. The leaves, except for the areas occupied by the lesions, are losing their green color. Numerous conidia are produced by such lesions. $C$, The lesions in midsummer. Few conidia are found at this time. $D$, Lesions which have extended into adjacent leaf tissue during the autumn. Conidia are produced on the newly involved areas. $E$, Necrosis of the leaf surface occupied by the lesions following the application of 3 per cent lime-sulfur. 
(Gorter, 1943) to warrant control measures. On Cyprus, however, control measures are not often necessary or profitable (Nattrass, 1935).

Judging from published accounts (Hayne, 1893; Bioletti and Colby, 1899; Horne, 1917; Horne, Essig, and Herms, 1923), the disease seldom has been important in California. Outbreaks since 1941, however, reduced the productiveness of some trees probably as much as 20 per cent. In one orchard, for example, defoliation amounting to 16 per cent in 1944, 13 per cent in 1945 , 14 per cent in 1946, and 9 per cent in 1947, resulted in the death of between 10 and 20 per cent of the fruiting wood in some trees.

Relation of the Age of Leaf to Infection. A relation between the age of leaf and the amount of infection was noted in the present studies. This phenomenon was not related to the number of seasons the leaf had been exposed to infection. On shoots produced in the summer of 1947, for example, spots appearing in 1948 were largely confined to the oldest 4 pairs of leaves. On 25 such shoots, which averaged 11 pairs of leaves, the average numbers of lesions per leaf on successive pairs from the base of the shoot were $5 \frac{1}{2}, 4,6$, $21 / 2,1 / 2,1 / 2,0,0,0,0,0$. Presumably each leaf on the shoot was subjected to equal chances of infection during the winter of 1947-48, yet the youngest 5 pairs remained free of the disease.

Influence of Environmental Conditions on the Disease. Petri (1913) believed that lack of lime in the soil increased the susceptibility of the tree to infection; but Anagnostopoulos (1937) found leaf spot severe on calcareous soils. Foëx (1924) reported the disease most prevalent on heavy soils where nitrogenous fertilizers were used. According to Anagnostopoulos (1937), in olive orchards interplanted with cereals or fodder crops the soil moisture and organic matter are depleted and severe damage from leaf spot follows.

Infection frequently is most prevalent on leaves in the lower parts of the tree. Some (Giulivo, 1927) believe this occurs because leaves so located remain moist after rains longer than those in the upper parts where air circulates more freely. Another explanation of this situation, of course, is that since conidia are washed downward by rains, leaves in the lowermost branches are more frequently infected than those on branches higher in the tree. According to our observations, location of the trees with respect to exposure to sunlight and air movement apparently does influence the severity of leaf spot, since trees along the east or south border of orchards were affected by leaf spot less than those inside the orchard. The relation of rains to infection of olive leaves by this fungus is discussed in a later section.

The outbreaks in California, beginning about 1940 and continuing to the present time (1948), have not been confined to particular localities but occurred in many olive-producing districts throughout the state. To determine if weather conditions might be correlated with the increased activity of the fungus between 1940 and 1948, records of the state's average mean temperature and rainfall for the months from September through April were compiled for each season since 1897-98. These data were plotted and examined for departures from the 50 -season averages.

The 50-season average September-through-April rainfall was 22.6 inches and the average number of rainy days per season was 48 . The amount of rainfall and the number of rainy days exceeded these averages during two of the 
three seasons (1936-37 to 1938-39) prior to the first observed severe outbreak of leaf spot in 1941. During the four seasons, 1939-40 to 1942-43, when the disease successively increased in severity throughout the state, the amount of rainfall and the number of rainy days exceeded the averages by 6.2 inches and 10.5 days per season. From 1943-44 to 1946-47, when leaf spot maintained a high degree of activity in orchards where it became established earlier, the rainfall was below, but the number of rainy days was above average.

For the twenty-three seasons prior to 1939-40, on the other hand, rainfall and the number of rainy days exceeded the average in but six seasons, only two of which occurred consecutively at any one time. A period when rainfall was at or below the average occurred between 1897-98 and 1902-03.

From 1903-04 to 1915-16, however, three periods of above-average rainfall occurred as follows: four consecutive years from 1903-04 to 1906-07, three from 1908-09 to 1910-11 and three from 1913-14 to 1915-16. In these three periods though total precipitation and the number of rainy days were comparable to those in the period between 1939-40 and 1942-43, apparently no serious outbreaks of leaf spot developed (Horne, 1917).

Mean temperatures for the period from 1939-40 to 1942-43 varied somewhat from the average. Apparently the fall and spring months were slightly cooler and the midwinter months slightly warmer than usual. Only one (1903-04 to 1906-07) of the other three periods of above-normal rainfall also had above-average mean temperatures during midwinter. Whereas mean temperatures of fall and spring months commonly are within the range $\left(60^{\circ}\right.$ to $\left.68^{\circ} \mathrm{F}\right)$ where the fungus makes its best growth on artificial media, the mean temperatures of the midwinter months usually are below it. Somewhat warmer weather during midwinter probably would aid the fungus, especially as favorable moisture conditions are most likely to occur at this time.

\section{THE CAUSAL ORGANISM}

Name and Description of the Fungus. Castagne (1845) named the fungus Cycloconium elaeaginum, but Boyer (1891) introduced the Latinized spelling of the species name, oleaginum.

Cycloconium oleaginum produces elongate-ovoid to pyriform, one- or two-celled, greenish-yellow to yellowish-brown conidia on short globose conidiophores (fig. 2), which arise from the subcuticular mycelium. Conidia vary from 14 to $27 \mu$ in length by 9 to $15 \mu$ in width (average 21 by $11 \mu$ ). They may be straight or with the terminal cell somewhat curved (fig. 2, $C$ ). The spore wall is smooth at first but later becomes somewhat thickened and rough.

Fig. 2. $A$ and $C$, Conidia of $C y$ cloconium oleaginum in place on the conidiophores. $B$, Two-celled conidium (c) detached from the globose conidiophores $(c p)$.

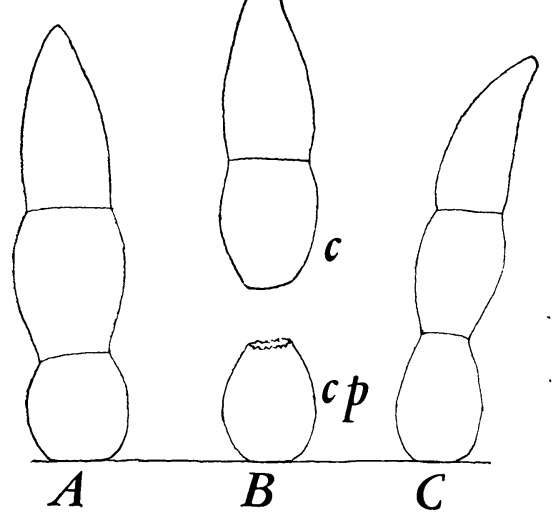


When mature the conidia are readily detached from the condiophore (fig. 2, $B$ ) by water.

The mycelium of the fungus is sparse in the host tissue, being composed of a thin layer of hyphae beneath the cuticle of the upper leaf surface. Boyer (1891) says that the mycelium in the living leaf seldom if ever penetrates beneath the epidermal.layer.

Studies by the junior author on the relation between the fungus and the leaf tissue are to be published as a separate paper.

Germination of Conidia. When the conidium germinates, a segment of the spore wall breaks at one or both ends; and at favorable temperatures hyaline to very light brown germ tubes emerge from the breaks after 36 to 48 hours. The germ tube near the conidium soon develops numerous septa. After reaching a length of 50 to $60 \mu$ it produces stout, lateral, often dichotomous branches.

To observe the effect of temperatures on germination, conidia were taken from newly developed lesions, those for any one test being washed from a single lesion; and a suspension of the spores was prepared in sterile, distilled water. Spores were held for germination in the following ways : (1) Uniformsized drops of spore suspension were spread over clean 15-mm cover glasses attached to microscope slides. The slides were supported on glass rods in petri dishes containing moistened filter paper. (2) One cubic centimeter of spore suspension was flooded over the surface of water-agar in petri dishes.

At any given temperature, germination occurred in a much shorter time in the water drops than on the agar plates. With time, however, the percentage of spores germinating on agar plates compared favorably with that in the water drops. Results of trials in water drops were as follows :

\begin{tabular}{|c|c|c|c|c|}
\hline \multirow{2}{*}{$\begin{array}{c}\text { Temperature } \\
\text { in degrees centigrade }\end{array}$} & \multicolumn{4}{|c|}{ Per cent spores germinating after } \\
\hline & 7 hrs. & $18 \mathrm{hrs}$. & $36 \mathrm{hrs}$ & $72 \mathrm{hrs}$. \\
\hline 6 & 0 & 0 & 0 & 0 \\
\hline 9 & 0 & 3 & 5 & 27 \\
\hline 12 & 15 & 22 & 25 & 50 \\
\hline 16 & 20 & 35 & 42 & 61 \\
\hline 20 & 34 & 40 & 58 & 62 \\
\hline 25 & 25 & 27 & 30 & 35 \\
\hline 30 & 0 & 0 & 3 & 4 \\
\hline
\end{tabular}

Conidia germinated readily between $9^{\circ}$ and $25^{\circ} \mathrm{C}$, but the highest germination occurred at $16^{\circ}$ and $20^{\circ}$. At $12^{\circ}$ and $20^{\circ}$ the germ tubes after 72 hours were 90 to $100 \mu$ long, at $9^{\circ}$ and $25^{\circ}$ not more than 20 to $30 \mu$ long.

Growth Characteristics of the Fungus on Artificial Media. Brizi (1894) attempted unsuccessfully to isolate and grow Cycloconium oleaginum. According to his account the conidia germinated readily in water, but the germ tube ceased growing after attaining a considerable length. As a result of his trials he concluded that the fungus can subsist only on the material it obtains from the cuticle of the living leaf.

Apparently Petri (1913) was the first to grow Cycloconium oleaginum in culture. He states that on a medium composed of extract from green olive leaves and agar, the fungus produced after 20 days a small hemispherical stromatic body, olive brown in color. Only in one series of cultures on oliveleaf extract acidified with tartaric acid did he obtain conidia. 
In our tests, as noted earlier, only 50 to 60 per cent of the conidia germinated under the most favorable conditions. Subsequent growth of the germ tube and development of mycelium were very slow. Because of this and the fact that bacteria and other fungi were commonly present in or on the lesions, it was difficult if not impossible to isolate Cycloconium oleaginum by planting leaf material in the usual manner. Consequently, conidia were taken from newly formed lesions. The conidia suspended in water were flooded over the surfaces of water agar in petri dishes, and after a few minutes the excess liquid was poured off. One or two hours were then allowed for drying of the agar surface, after which the conidia were picked off and planted on solid media in test tubes, flasks, or petri dishes. In this way five to ten pure cultures were obtained from thirty to forty transfers. But if the spores were transferred (with bits of medium) after they germinated, the germ tubes ceased growing.

By transferring the conidia before they germinated, the fungus was successfully grown on the following media : potato-dextrose agar, prune agar, cornstarch agar, water agar plus 1 per cent olive oil, and water agar plus water extracts from green olive leaves. Two weeks or more were required for the fungus to produce a visible growth on the leaf-extract agar, the most favorable medium. Here, mycelium on the surface was much more luxuriant than below. The same was true of prune agar. On potato-dextrose agar, however, mycelium was more extensive below than on the surface. Cornstarch agar and water agar plus olive oil proved the least favorable media.

The growth characteristics of Cycloconium oleaginum on olive-leaf-extract agar were as follows: Early growth of the fungus was confined to the substratum. Hyphae below the surface produced numerous chlamydospores, which usually were intercalary but sometimes terminal. These cells were spherical to oval, dark brown, thick-walled, and filled with refractive granules, probably of a fatty nature. Occasionally a conidium was formed at the end of a hyphal branch. This conidium usually germinated in place, giving rise to a continuation of the hyphal strand.

After 2 to 3 weeks the colony became visible to the naked eye as a dark, olivebrown spot. Aerial hyphae were formed which grew more rapidly than the hyphae in the substratum and gave rise to a hemispherical body with a grayisholive, feltlike surface.

After four months' growth, the hemispherical body developed distinct layers. The basal layer was composed of loosely interwoven, segmented mycelium submerged in the medium. Certain hyphae of this layer formed spherical or oval segments resembling chlamydospores. These were darker brown and with thicker walls (fig. 3, $A$ ) than the hyphae. The next stratum of the colony rose above the surface of the agar and formed the center of the hemispherical stromatic mass. This stratum consisted of short, thickened, darkbrown to black hyphae, which were so closely interwoven as to resemble a parenchymatous structure (fig. $3, B$ ). This structure probably was not a stroma in the morphological sense : so far as has been determined, no reproductive structures are produced on it. However, cavities with internal hyaline cellular structure, suggesting perithecial or pycnidial primordia, have been observed (fig. $3, B$ ) in culture. No further development of these bodies occurred in culture after six months' time. The external stratum consisted of 
hyaline to light-brown, loosely interwoven hyphae, which grew out of the stromatic layer and formed a feltlike surface over it (fig. 3, $C$ ).

Certain hyphae submerged in the agar developed structures resembling microsclerotia. Such hyphae usually were larger in diameter, with shorter and thicker segments, than others. A single hypha formed short lateral branches which united; or two hyphae growing together formed a single vesicle at the union. From this vesicle arose a mass of dark, thick-walled, parenchymalike
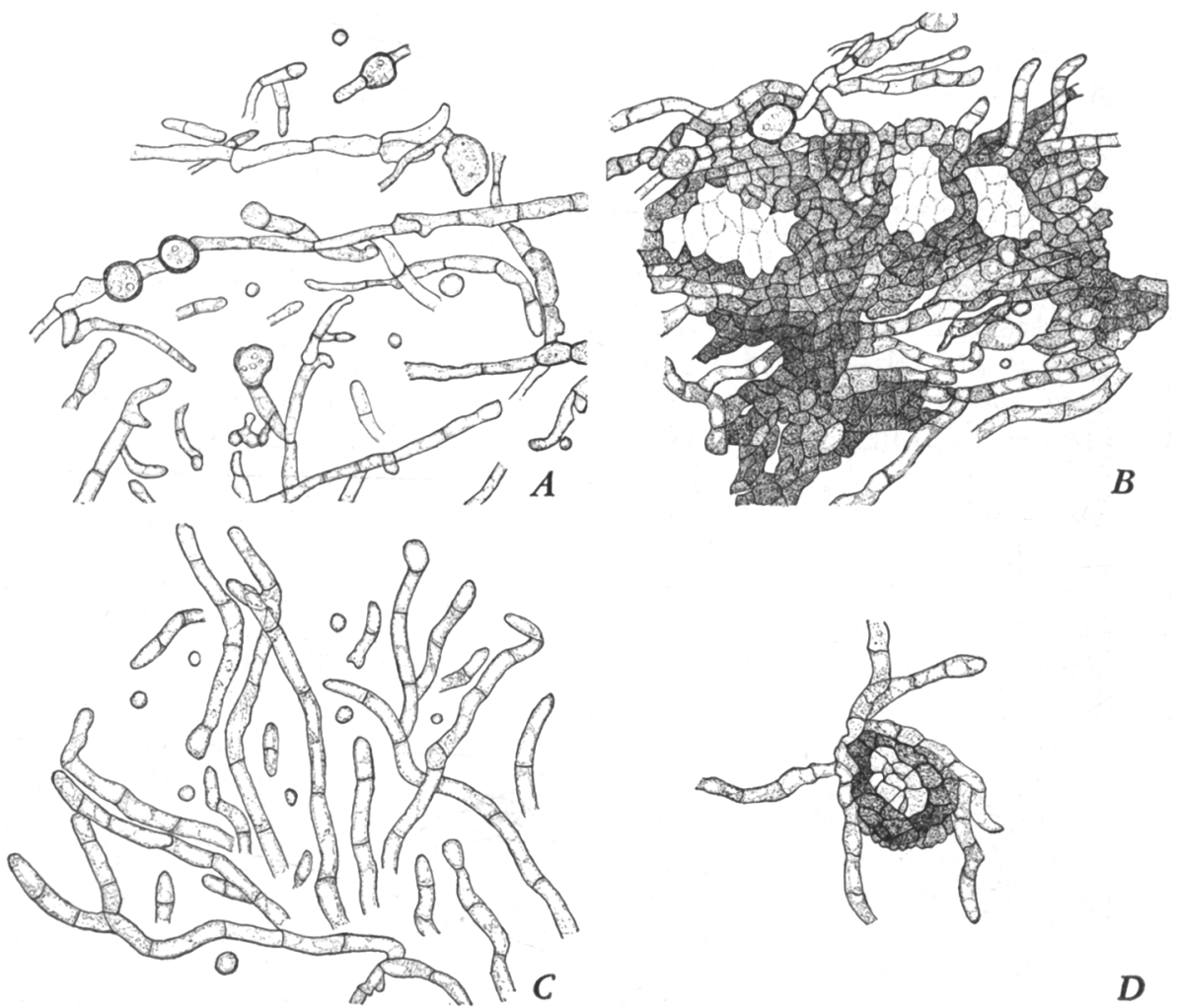

Fig. 3. Cross sections through four-month-old colony of $C$. oleaginum grown on olive-leafextract agar (all $\times 550): A$, Basal layer of colony, showing thick-walled chlamydospores, and loosely interwoven hyphae. $B$, Stromatic layer of colony, showing parenchymatous nature of mycelial growth, and cavities composed of hyaline cells within the stromatic mass. $C$, Aerial portion of colony which makes up a feltlike surface over the stromatic layer. $D$, Microsclerotiumlike body occurring in the basal layer of the colony.

cells. These sclerotiumlike bodies, after further growth, were composed of a thick cortical outer layer of dark-colored cells surrounding a central mass of thin-walled hyaline cells, rich in granular protoplasmic content (fig. $3, D$ ). The function of these structures has not been ascertained. They have not been seen to develop further nor to produce fruiting structures. Petri (1913), who described similar structures in his cultures, believed they might be sporocarps arrested in a primary stage of development. 
Relation of Temperature to Growth of the Fungus in Culture. For the temperature trials, conidia were obtained from a single lesion in the manner described earlier. These conidia were planted on olive-leaf-extract agar in petri dishes and incubated at the various temperatures for 2 months.

Cycloconium oleaginum grew within a temperature range from $9^{\circ}$ to $30^{\circ}$ C (fig. 4). Apparently the optimum temperature for mycelial growth was between $16^{\circ}$ and $20^{\circ}$, both the width and height of the colony being greater at these temperatures. Compared to most other fungi, however, C. oleaginum grew very slowly. At the most favorable temperature, the colony became
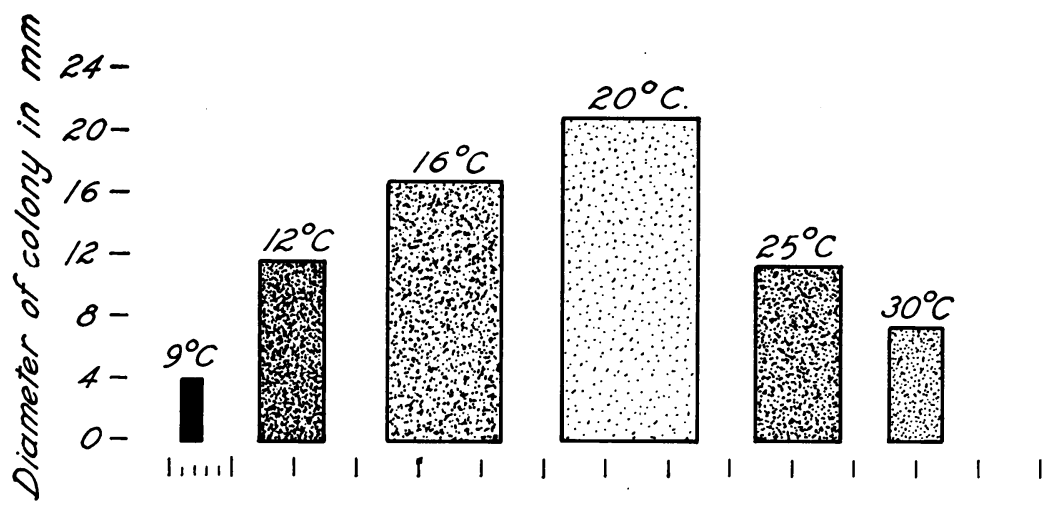

Height of stromatic mass indicated by width of column. (large scale divisions equal one centimeter). Darkness of colony indicated by shading.

Fig. 4. Relation of temperature to growth and color of the stromatic masses of Cycloconium oleaginum on olive-leaf-extract agar.

visible only after 2 or 3 weeks, and attained a diameter of not over $2 \mathrm{~cm}$ after 2 months. The color of the colony ranged from jet black at $9^{\circ}$ to gray at $20^{\circ}$ (fig. 4).

Production of Conidia by Different Isolates. Many single-spore isolates of Cycloconium oleaginum were grown comparatively on different media and under different environmental conditions. Among nine isolates obtained in March, 1947, and grown on olive-leaf-extract agar at room temperature near a window, three produced abundant typical conidia.

The three sporulating isolates produced small brown hyphal masses, the surfaces of which were deeply convoluted and pulverulent. This contrasted with the larger, regularly hemispherical, grayish stromalike masses with feltlike surfaces produced by the nonsporulating type. Single-spore subisolates from the sporulating type grown under a variety of environmental conditions always developed into the typical nonsporulating type. The behavior of the two types of isolates cannot be explained at this time. The existence of definite conidial and mycelial types suggests the dual phenomenon observed in other fungi (Hansen, 1938; Hansen and Snyder, 1945) ; but the failure to obtain further segregation into the two types does not accord with this phenomenon. 


\section{LIFE CYCLE OF THE FUNGUS IN RELATION TO DISEASE PRODUCTION}

Survival of the Fungus from Year to Year. In central California the activity of Cycloconium oleaginum is low throughout the hot, dry summer months. The fungus passes this period as mycelium in diseased leaves on the tree; but whether or not it survives in leaves which fall to the ground remains undetermined. Some (Bernès, 1923) apparently believe this occurs, since recommendations for control of leaf spot in France include the collection and burning of fallen leaves.

Source of Conidia for New Infection. That lesions on leaves in the tree are important sources of conidia for new infection is suggested by the following evidence : In one orchard Manzanillo olives developed the leaf spot only in trees adjacent to affected Mission trees, though fallen diseased leaves frequently were carried by winds well into the interior of the Manzanillo block. Moreover, olive seedlings and root suckers growing beneath the branches of diseased orchard trees were heavily infected by leaf spot; whereas seedlings not located beneath the drip of the orchard trees, but growing in nearby places to which diseased fallen leaves were blown, remained comparatively free from infection.

Conidium production by lesions on leaves which remained in the tree varied with the season of the year. For a time after new lesions appeared in early spring numerous conidia were produced. During the summer and early fall few viable conidia were found on these lesions. But in late fall (October or November) the margins of the lesions began extending laterally into the adjacent leaf tissue and numerous conidia developed on them (fig. 1, D). Thus, an abundant supply of inoculum was present by late November.

Dissemination of Conidia from Infected Trees. The spread of leaf spot from Mission to Manzanillo olive trees was mentioned in the foregoing section. Here the incidence of leaf infection diminished rapidly as horizontal distance from the Mission trees increased. Manzanillo trees in the row adjacent to the Mission trees lost 20 to 25 per cent of their foliage, but very few lesions could be found in Manzanillo trees located seven rows from the Mission.

In other orchards the disease spread from unsprayed to sprayed trees. In these cases, also, the spread of leaf spot was confined to the first one or two rows of sprayed trees adjacent to the unsprayed block.

This apparently restricted aerial dissemination might be explained in a number of ways, one being that conidia are not easily detached and carried away from the lesions by wind. When a jet of air was blown over leaf lesions bearing numerous conidia, for instance, only a few were caught on oil-coated glass slides placed a few inches away. On the other hand, drops of water, allowed to fall on the lesions, carried away conidia in large numbers. Possibly, therefore, some of the conidia, at least, are disseminated from tree to tree in wind-blown droplets of water that have been spattered from lesions. These spore-laden droplets of water, being of appreciable size and weight, settle rapidly, and, are readily deposited on objects, such as foliage, in their path. Thus through settling and interception by foliage the number of wind-blown droplets rapidly diminishes as distance from the source increases. 
Conidia are most certainly washed downward from lesions in the upper part of the trees, and this downward dissemination accounts-in part at least-for the greater prevalence of the disease in the lower than in the upper parts of the tree.

Time of Natural Infection and of Development of the Lesions. Apparently no earlier investigator determined the time of the year natural infection occurs. To obtain information on this point, we exposed small olive trees in 5 -gallon cans beneath diseased orchard trees. At intervals the trees were removed to a lath-house and replaced by others. The 1945-46 experiments proved unsuccessful, but results secured in 1946-47, and appearing in figure 5, indicate that infection was initiated at various times between November and late February.

Failure to obtain infection on trees exposed between November 2 and 22 (fig. 5) might have been due to weather conditions; or scarcity of inoculum might have been the cause, because expansion of old lesions and the consequent production of new conidia had just begun when these trees were placed in the orchard.

Interestingly enough, the heaviest infection of the season occurred in late December, when temperatures ranged between $42^{\circ}$ and $52^{\circ} \mathrm{F}\left(6.0^{\circ}-11.5^{\circ} \mathrm{C}\right)$. Petri (1913) found a temperature of $53^{\circ} \mathrm{F}$ ( $12^{\circ} \mathrm{C}$ approx.) to be optimum for spore germination, but according to our studies the optimum is between $61^{\circ}$ and $68^{\circ} \mathrm{F}\left(16^{\circ}\right.$ and $\left.20^{\circ} \mathrm{C}\right)$. Regardless of whether or not the lower temperatures are favorable for entry of the fungus into the host, leaf infection in 1946-47 apparently proceeded during the colder winter weather when other conditions were favorable.

Appreciable infection was initiated in a period of low rainfall between December 11 and 23, 1946, though none occurred in a period of low rainfall between December 30 and January 29. During the former period, olive foliage was kept moist for several hours at a time by heavy fogs, whereas only one light shower and no fogs of consequence occurred during the latter period. While a relation between moisture and infection can be expected, and these data indicate such a relation, the information on this subject is incomplete and inconclusive.

The only successful case of infection we obtained by artificial inoculation occurred in three small trees sprayed with a spore suspension on November 12 and placed in a moist-chamber under outdoor conditions at Berkeley. A few lesions became visible on December 15, and others continued to appear during the latter half of the month. Assuming the fungus entered the leaves soon after the spores were sprayed on them, the incubation period was 4 to 6 weeks.

Observations on development of leaf-spot symptoms in the Sacramento Valley (except as otherwise noted), during the five seasons that fungicidal tests were made, follow :

1943-44 Season : No observations were made on the development of lesions during the fall of 1943 . The first signs of new lesions to appear after fungicidal tests were started on January 5, 1944, were numerous inconspicuous olivaceous spots which became visible early in February, and continued to appear until early March. Lesions were abundant during this season and defoliation of the trees severe. 


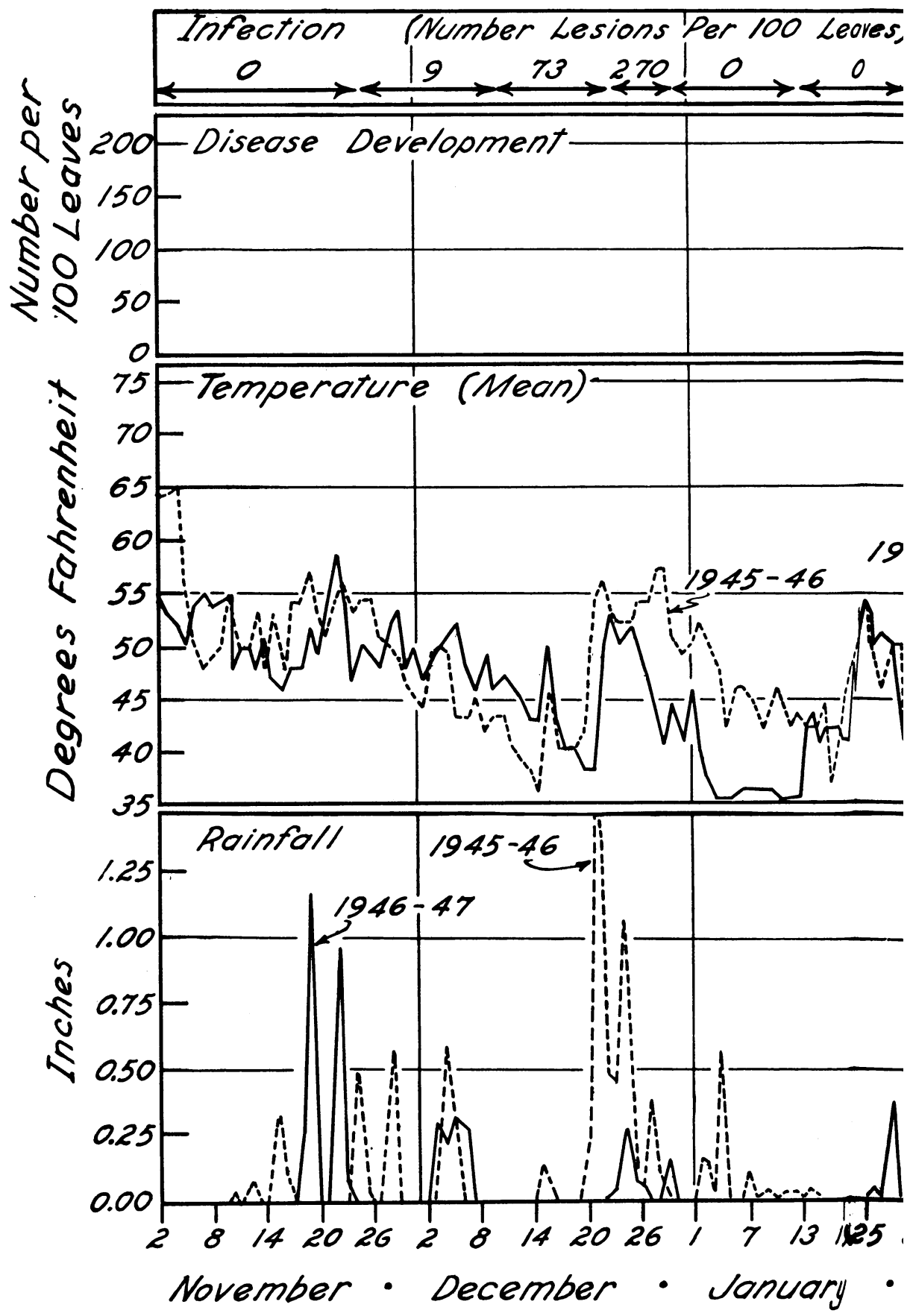

Fig. 5. Infection and development of olive leaf spot in relation to temperature and rainfall. At the top of the graph the periods during which young trees were kept beneath orchard trees in 1946-47 are indicated by arrows. The numerals refer to the number of lesions per 100 leaves developing on these trees the following spring. In the next section below, the 

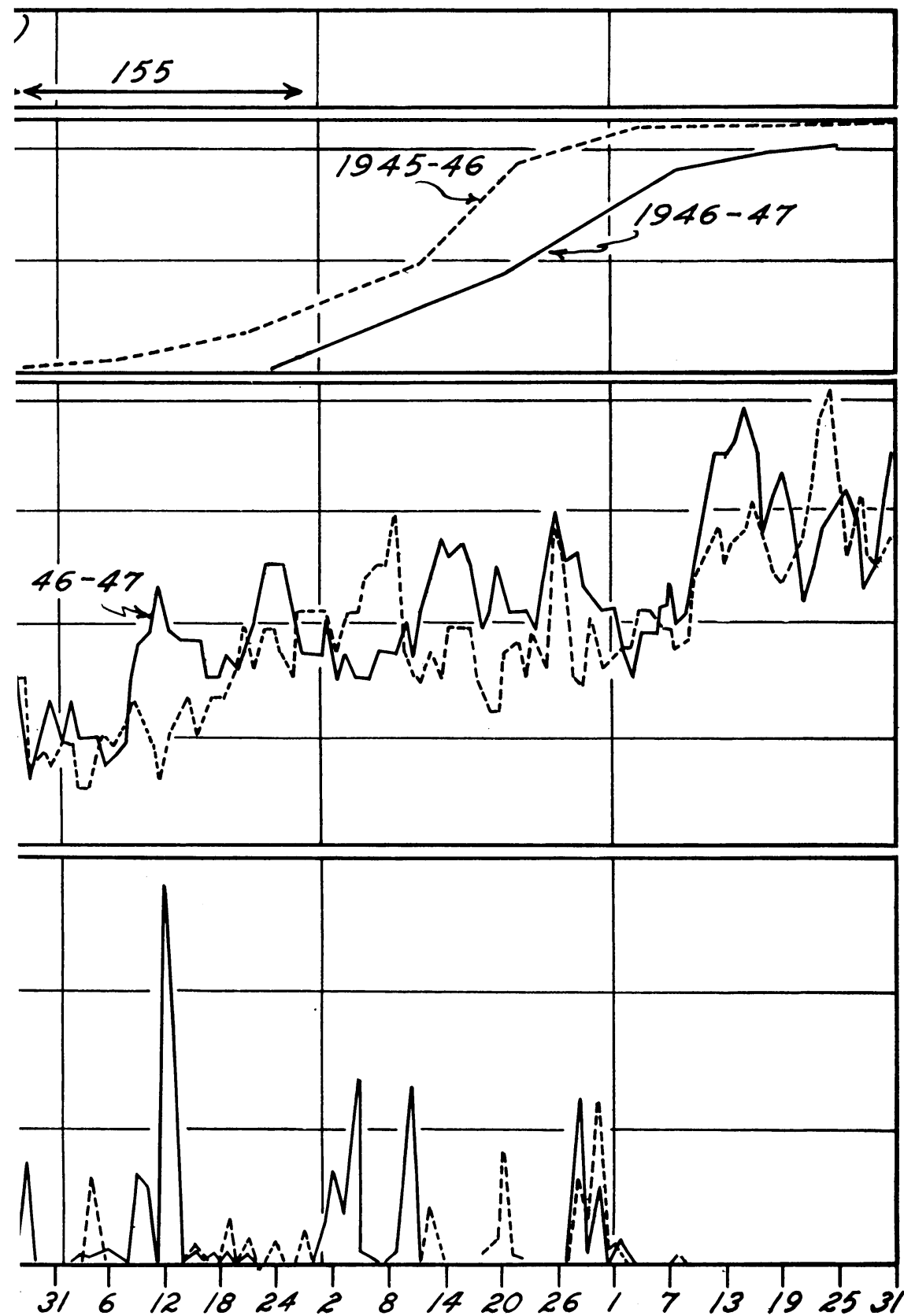

\section{- February - March - April}

average numbers of lesions per 100 tagged leaves are given for 1945-46 and 1946-47. Development of symptoms occurred on these leaves during February and March. Temperature and rainfall for the periods covered by the infection and disease development data are given in the other two sections. 
1944-45 Season: No new lesions were noticeable in the autumn or early winter of 1944-45, but a great number became visible the second week in February, and lesions continued to increase in numbers until early March. The disease was abundant and defoliation of the trees severe.

1945-46 Season: No signs of new lesions were visible in the fall and early winter of 1945-46. Abundant new lesions, however, began appearing the first week in February. Their development was followed on the leaves of 50 tagged terminal shoots. Increases in the number of leaf spots were recorded at all periods of observation between February 6 and March 7 (fig. 5). After this date, however, no further increases were noted, though observations were continued throughout April. The incidence of infection was somewhat lower than in 1944-45 but tree defoliation was almost as severe. Increases in lesion size and foliage yellowing and dropping continued through early June.

1946-47 Season : Lesion development was again followed on tagged twigs. The first symptoms became visible in early March. The number of lesions increased until the last observation was made on April 25. The incidence of infection was about half that of 1945-46. Defoliation continued well into June.

1947-48 Season: In a number of respects disease development during the season of 1947-48 differed from that of the previous four. Unlike the three preceding seasons, appreciable numbers of new lesions became visible at Orland in the Sacramento Valley during late October, 1947. Rains during the second week of October are suspected of having initiated the infection. At Berkeley and Palo Alto, both in coastal districts, new lesions appeared in early October. Here no rains of consequence had occurred for several months prior to the time the lesions became visible; hence infection possibly was initiated during periods of fog or high humidity.

At Orland further disease development did not occur until late January, when lesions began appearing and continued to increase in numbers for several weeks thereafter. Unlike the preceding seasons, disease development in 1947-48 continued into the spring and early summer. At least two major periods of lesion development were recorded after that beginning in January. One period occurred about the middle of May and was followed closely by the development of numerous new lesions the first part of June. Defoliation of the trees occurred from late June through July. The two later waves of disease development were preceded by rainy weather in April and May.

Judging from the results of observations and tests reported in this section, the fungus entered the olive leaf at various times in fall, winter, and spring. Except in 1947-48, lesions did not develop to a visible stage until late winter or early spring. The period of disease initiation and development, therefore, coincides with the rainy season. In 1947-48, rains occurring in early fall and late spring were followed within a few weeks by the development of new lesions. In other seasons, however, new lesions sometimes did not appear until 2 or 3 months after the beginning of the fall rains. In 1946-47, for example, young trees which were exposed to infection in late November developed no symptoms until about April 1. On the other hand, those exposed to infection in February developed symptoms only about 2 weeks after those exposed in November. Such variations between the length of the incubation periods in winter and spring may reflect the effect of temperature on fungus growth. 


\section{CONTROL WITH FUNGICIDES}

Recommendations that Cycloconium leaf spot be controlled by spraying with bordeaux mixture were made as early as 1898 (Vennuccini, 1898; Brizi, 1899). In 1901 and again in 1906 (Guozdenovic, 1901; Tobler and RossiFerrini, 1906) further tests, in Dalmatia and Italy, showed that the disease could be reduced by spraying with 1 per cent (approximately 8-8-100) bordeaux mixture.

The time of the year at which these workers applied the sprays is unknown to us. (The original papers of Vennuccini, Brizi, Guozdenovic, and Tobler and Rossi-Ferrini were not available to us.) Later recommendations for timing the applications have varied considerably. Thus spring and summer applications are suggested by some (Bernès, 1923; Giulivo, 1927), May and July applica-

TABLE 1

\section{CONTROL OF CYCLOCONIUM LEAF SPOT OF OLIVE TREES BY APPLICATIONS OF VARIOUS FUNGICIDAL SPRAYS}

\begin{tabular}{|c|c|c|}
\hline $\begin{array}{l}\text { Season, group, material (pounds per } 100 \text { gallons or per cent by volume), } \\
\text { and date of applying spray }\end{array}$ & $\begin{array}{c}\text { Average } \\
\text { number of } \\
\text { lesions on } \\
100 \text { leaves }\end{array}$ & $\begin{array}{l}\text { Range } \\
\text { in per cent } \\
\text { defoliation } \\
\text { in tree* }\end{array}$ \\
\hline \multicolumn{3}{|l|}{ 1943-44: } \\
\hline \multicolumn{3}{|l|}{ Group $A^{* *}$} \\
\hline Unsprayed. & 210 & $48-16$ \\
\hline Bordeaux, 8-8-100, Jan. 6, 1944 . & 60 & $26-9$ \\
\hline Bordeaux, 8-8-100, Feb. 5, $1944 \ldots \ldots \ldots \ldots \ldots \ldots$ & 90 & $35-7$ \\
\hline Bordeaux, 8-8-100, Jan. 6, 1944, and Feb. 5, $1944 \ldots \ldots \ldots \ldots \ldots \ldots$ & 40 & $12-1$ \\
\hline \multicolumn{3}{|l|}{ Group B } \\
\hline Unsprayed $\ldots \ldots \ldots \ldots \ldots \ldots \ldots \ldots \ldots \ldots \ldots$ & 250 & $52-18$ \\
\hline Ferric dimethyl dithiocarbamate, $2-100$, Feb. $5,1944 \ldots$ & 150 & $32-11$ \\
\hline \multicolumn{3}{|l|}{ 1944-45: } \\
\hline \multicolumn{3}{|l|}{ Group C } \\
\hline Unsprayed $\ldots \ldots \ldots \ldots \ldots \ldots \ldots$ & 842 & $47-6$ \\
\hline Bordeaux, 8-8-100, Dec. $18,1944 \ldots$ & 212 & $20-3$ \\
\hline Bordeaux, $8-8-100$, Dec. 18,1944 , and Jan. $12,1945 \ldots \ldots \ldots \ldots \ldots$ & 75 & $11-1$ \\
\hline Bordeaux, $8-8-100$, Dec. 18,1944 , and Feb. $20,1945 \ldots \ldots \ldots \ldots \ldots$ & 137 & $17-2$ \\
\hline \multicolumn{3}{|l|}{ Group D } \\
\hline Unsprayed.. & 623 & $36-12$ \\
\hline Bordeaux, 8-8-100, Jan. 12, 1945. & 207 & $29-9$ \\
\hline Bordeaux, $8-8-100$, Jan. 12,1945 , and Feb. $20,1945 \ldots \ldots \ldots \ldots \ldots \ldots$ & 214 & 24-6 \\
\hline \multicolumn{3}{|l|}{ Group E } \\
\hline Unsprayed... & 502 & $39-13$ \\
\hline Bordeaux, 8-8-100, Jan. 12,1945 . & 112 & $19-6$ \\
\hline Bordeaux, 8-8-100, Feb. 20, 1945 & 217 & $31-5$ \\
\hline \multicolumn{3}{|l|}{ Group F } \\
\hline Unsprayed.... & 587 & $37-10$ \\
\hline Zinc dimethyl dithiocarbamate, Jan. 12,1945 , and Feb. $20,1945 \ldots$ & 574 & $31-12$ \\
\hline \multicolumn{3}{|l|}{ Group G } \\
\hline Unsprayed.... & 365 & 29-8 \\
\hline Copper sulfate-borax-lime, 4-3-1-100, † Jan. 12, 1945, and Feb. 20, 1945. . & 388 & $31-11$ \\
\hline Bordeaux, 8-8-100, plus borax, $3-100, \dagger \operatorname{Jan} .12,1945$, and Feb. $20,1945 \ldots$ & 95 & $12-3$ \\
\hline
\end{tabular}

* Defoliation in bottom and top of tree respectively.
** In 1943-44 to 1945-46, plots grouped together were located in the same part of the orchard. Results from treatments are to be compared with the results for the check plot in the same group.

$\dagger$ Borax solution was mixed with copper sulfate solution, lime suspension was then added. In the next preparation, a borax solution was added to bordeaux mixture. 
TABLE 1 (Concluded)

\begin{tabular}{|c|c|c|}
\hline $\begin{array}{l}\text { Season, group, material (pounds per } 100 \text { gallons or per cent by volume), } \\
\text { and date of applying spray }\end{array}$ & $\begin{array}{l}\text { Average } \\
\text { number of } \\
\text { lesions on } \\
100 \text { leaves }\end{array}$ & $\begin{array}{l}\text { Range } \\
\text { in per cent } \\
\text { defoliation } \\
\text { in tree* }\end{array}$ \\
\hline \multicolumn{3}{|l|}{ 1945-46: } \\
\hline Unsprayed........ & 444 & $38-15$ \\
\hline Bordeaux, $10-10-100$, Nov. $13,1945 \ldots \ldots \ldots \ldots \ldots \ldots$ & 22 & $11-1$ \\
\hline Bordeaux, 10-10-100, Nov. 13, 1945, and Jan. 22, 1946. & 4 & $6-0.5$ \\
\hline Bordeaux, 10-10-100, Dec. 12, $1945 \ldots \ldots \ldots \ldots \ldots \ldots$ & 7 & $3-0.3$ \\
\hline \multicolumn{3}{|l|}{ Group I } \\
\hline Unsprayed $\ldots \ldots \ldots \ldots \ldots \ldots \ldots \ldots \ldots \ldots \ldots$ & 300 & $34-11$ \\
\hline Bordeaux, 10-10-100, Dec. 12, 1945, and Jan. 22, 1946.......... & 4 & $4-0.2$ \\
\hline Bordeaux, 10-10-100, Nov. 13, 1945, Dec. 12, 1945, and Jan. $22,1946$. & 3 & $3-0.2$ \\
\hline 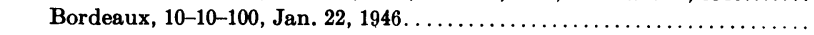 & 150 & $17-13$ \\
\hline \multicolumn{3}{|l|}{ Group J } \\
\hline 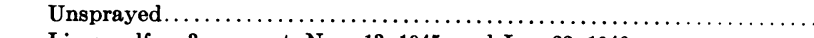 & 600 & 58-27 \\
\hline Lime-sulfur, 3 per cent, Nov. 13, 1945, and Jan. 22, 1946... & 7 & $7-0.7$ \\
\hline Lime-sulfur, 3 per cent, Dec. 12, 1945, and Jan. 22, 1946... & 9 & $5-0.7$ \\
\hline \multicolumn{3}{|l|}{ Group K } \\
\hline 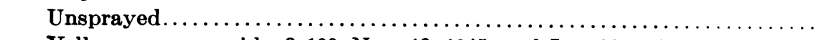 & 444 & $38-12$ \\
\hline Yellow cuprous oxide, $3-100$, Nov. 13,1945 , and Jan. $22,1946 \ldots \ldots$ & 10 & 24-20‡ \\
\hline \multicolumn{3}{|l|}{ Group L } \\
\hline 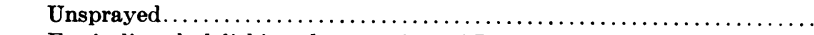 & 372 & $49-17$ \\
\hline Ferric dimethyl dithiocarbamate, $2-100, \S$ Dec. 12, 1945, and Jan. $22,1946 \ldots$ & 39 & $12-7$ \\
\hline Zinc dimethyl dithiocarbamate, $2-100, \S$ Dec. 12,1945 , and Jan. $22,1946 \ldots$ & 48 & $16-10$ \\
\hline \multicolumn{3}{|l|}{ 1946-47: } \\
\hline Unsprayed...................... & 177 & $17-5$ \\
\hline Bordeaux, 10-10-100, Nov. 26, $1946 \ldots \ldots$ & 4 & $1-0.3$ \\
\hline Bordeaux, 10-10-100, Jan. 21, 1947.............. & 100 & $9-2$ \\
\hline Bordeaux, 10-10-100, Nov. 26, 1946, and Jan. 21, $1947 \ldots$ & 2 & $1-1$ \\
\hline Lime-sulfur, 3 per cent, Nov. $26,1946 \ldots \ldots \ldots \ldots \ldots \ldots \ldots$ & 1 & $3-0.2$ \\
\hline Lime-sulfur, 3 per cent, Jan. $21,1947 \ldots \ldots \ldots \ldots \ldots \ldots \ldots \ldots$ & 132 & $10-3$ \\
\hline Lime-sulfur, 3 per cent, Nov. 26, 1946, and Jan. $21,1947 \ldots \ldots$ & 2 & $1-0.5$ \\
\hline \multicolumn{3}{|l|}{$1947-48: 9$} \\
\hline Unsprayed.......... & 528 & $\ldots \ldots$ \\
\hline Bordeaux, 10-10-100, Nov. 25, $1947 \ldots \ldots$. & 189 & $\ldots \ldots$ \\
\hline Lime-sulfur, 3 per cent, Nov. 11, 1947... & 338 & $\ldots \ldots$ \\
\hline Limo-sulfur, 3 per cent, Nov. $25,1947 .$. & 262 & $\ldots$. \\
\hline Lime-sulfur, 3 per cent, Dec. 16, 1947. . & 242 & $\ldots$. \\
\hline
\end{tabular}

* Defoliation in bottom and top of tree respectively.

** In 1943-44 to 1945-46, plots grouped together were located in the same part of the orchard. Results from treatments are to be compared with the results for the check plot in the same group.

† Borax solution was mixed with copper sulfate solution, lime suspension was then added. In the next preparation, a borax solution was added to bordeaux mixture.

$\$$ The major part of the defoliation was caused by spray injury.

$11 / 2$ gallons of Ortho-Adhesive was added to each 100 gallons of these preparations.

Statistical data for 1947-48:

Calculated $F$ value, 58.7.

Difference for significance: 19:1 odds, 43.5; at 99:1 odds, 63.3.

tions by others (Marinangeli, 1928), and late spring and winter applications by still others (Nattrass, 1935). In South Africa (Gorter, 1943) 8-8-100 bordeaux satisfactorily controlled the disease when applied in winter and again in spring after the trees had blossomed and some new leaves had developed.

The fungicidal tests we conducted are summarized in table 1 . These tests consisted in applying each treatment to two or more plots (4 in 1946-47) in the same orchard. Large variations in the severity of the disease occurred in different areas of the orchard used during 1943-44, 1944-45, and 1945-46; consequently, statistical analyses of the data on control were not feasible. In- 
stead the average results from each treatment are given (table 1) with the average results of the nearest check plots. In 1946-47 and 1947-48, however, experiments were conducted in an orchard where the incidence of the disease varied but little from one part to another; consequently analyses of variance of the data for these seasons were feasible though the differences between

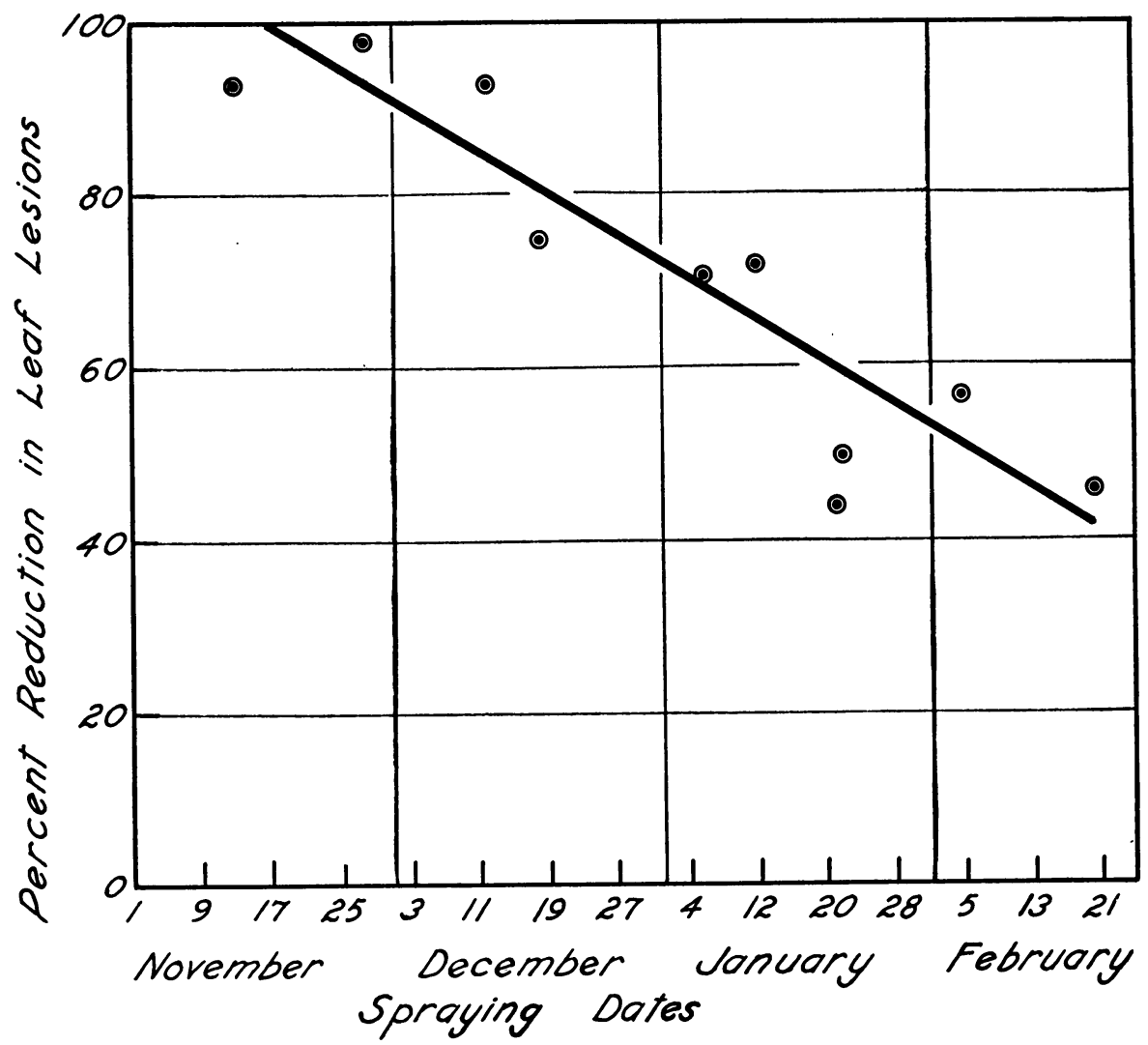

Fig. 6. Relation of the time of applying bordeaux spray during the infection season to control of olive leaf spot. Progressively poorer control accompanied successive delays in applying the spray.

treatment and nontreatment were so great in the former season as to require no such analysis.

Timing of the First Spray Treatment. According to evidence secured by exposing young olive trees to infection in the orchard and reported earlier in this paper, the disease was initiated at any time throughout late fall, winter, and early spring. Lesions resulting from infection during these seasons appeared in large numbers from February through April, but few appeared thereafter. Apparently, therefore, the period of disease activity corresponded roughly to the rainy season.

Hence with a protective fungicide, such as bordeaux, one might expect most effective control if the treatment is given in fall or early winter before 
infection is initiated. This held true for the years between 1944 and 1947 (fig. 6). From results secured in these seasons the per cent reduction in the number of new leaf lesions from a single application of bordeaux is plotted against the time of the year in which the bordeaux treatment was given. Control of leaf spot became successively poorer as application of the fungicide was delayed until later and later in winter. For example (table 1), the November 26,1946 , treatment reduced leaf infection 98 per cent, whereas the January 21, 1947, treatment reduced infection only 44 per cent. Much the same results were secured with lime-sulfur this same season, as is shown in table 1. In 1947-48, however, a treatment of bordeaux given November 25, 1947, failed to prevent extensive infection which was initiated earlier in the autumn.

Fall or early-winter applications create a problem of spray residue on the fruit. Although all of the fruit for pickling is harvested before mid-November, the fruit for oil usually remains on the tree well into January. Though early December applications of bordeaux gave fairly satisfactory control of leaf infection in some years, January applications were much less effective. If bordeaux or any other residue-depositing fungicide is to be used against the disease before harvest, the problem of either removing the residue from the fruit or delaying application of the spray until the fruit is picked must be solved.

Type of Fungicide. Although bordeaux mixture was the material most frequently used in these tests, lime-sulfur, ferric dimethyl dithiocarbamate (FDDC, or Fermate), zine dimethyl dithiocarbamate (ZDDC, Zerlate), and yellow cuprous oxide (Yellow Cuprocide) were also applied in certain years. Because trees in the experimental orchard exhibited leaf and fruit symptoms resembling those of boron deficiency, two borax-containing preparations were applied in 1944-45. One preparation was made by mixing a solution of borax (3-100) with a solution of copper sulfate (4-100), thus forming copper borate. To neutralize any soluble copper that might be present, a weak suspension (1-100) of lime was added. The second preparation consisted of 8-8-100 bordeaux to which had been added a borax solution (3-100).

The treatment with ferric dimethyl dithiocarbamate (FDDC), 2-100, on February 4, 1944, which reduced leaf spot only 40 per cent, was definitely too late for most effective control, since 8-8-100 bordeaux applied at the same time reduced infection only 57 per cent. A two-treatment program of zinc dimethyl dithiocarbamate (ZDDC) 2-100, on January 12, 1945, and February 20,1945 , proved ineffective. Here also the first treatment was given too late for best control ; still, a parallel two-treatment program of 8-8-100 bordeaux reduced leaf spot 64 per cent. In 1945-46, two-treatment programs of FDDC and ZDDC, both at 2 pounds per 100 gallons of water and containing $11 / 2$ gallons of an emulsifiable petroleum oil (Ortho-Adhesive) per 100 gallons, gave fairly good control, though not so satisfactory as that given by bordeaux mixture applied at the same time. Further tests would, of course, be necessary to determine the advantages of adding a supplement to these materials.

Yellow cuprous oxide, 3-100, in a two-treatment program, controlled leaf spot effectively but caused injury to the leaves, which precludes its use as a spray for olives. 
The copper-sulfate-borax-lime preparation was ineffective against the disease in the 1944-45 trials. The bordeaux-borax preparation, on the other hand, reduced infection 76 per cent, whereas a bordeaux preparation without borax reduced it 64 per cent. Since borax preparations did not correct the borondeficiency-like symptoms, they were not tested further.

TABLE 2

CONTROL OF CYCLOCONIUM LEAF SPOT BY ONE OR MORE TREATMENTS OF BORDEAUX

\begin{tabular}{|c|c|c|}
\hline Season & Dates of applying bordeaux treatments* & $\begin{array}{l}\text { er cent reduction } \\
\text { in the incidence } \\
\text { of leaf spot }\end{array}$ \\
\hline $1943-44$ & 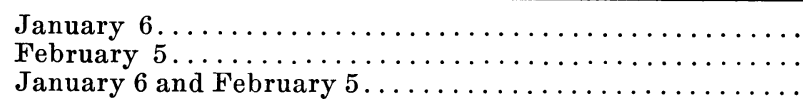 & $\begin{array}{l}71 \\
57 \\
81\end{array}$ \\
\hline $1944-45$ & 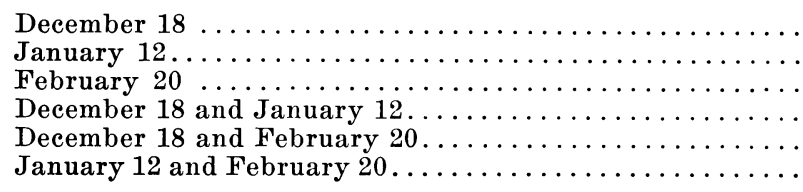 & $\begin{array}{ll}\cdots & 75 \\
\cdots & 67 \\
\cdots & 55 \\
\cdots & 91 \\
\cdots & 84 \\
\cdots & 66\end{array}$ \\
\hline $1945-46$ & 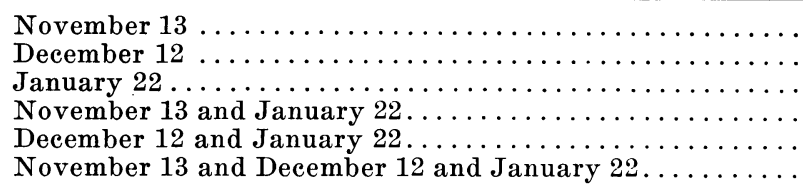 & $\begin{array}{ll}. & 95 \\
\cdots & 98 \\
\cdots & 50 \\
\cdots & 99 \\
\cdots & 99 \\
\cdots & 99\end{array}$ \\
\hline
\end{tabular}

* Bordeaux 8-8-100 in 1943-44 and 1944-45; 10-10-100 in 1944-46.

In 1945-46 and 1946-47, 3 per cent lime-sulfur in one- or two-treatment programs controlled the disease as effectively as parallel programs of bordeaux. In 1947-48, however, neither bordeaux nor lime-sulfur proved highly satisfactory in single treatments. One reason for this unsatisfactory performance, it has been noted, was extensive leaf infection prior to the time of treatment. Judging from the data in table 1, which were secured June 3, 1948, bordeaux proved more effective than lime-sulfur applied at the same time (November 25). It will be noted, moreover, that the November 25 and December 16 lime-sulfur treatments were somewhat more efficacious than the November 11 treatment. Counts made in March showed lime-sulfur to equal bordeaux in its effectiveness. Between March and June, leaf spot developed much more extensively in lime-sulfur sprayed trees than in those receiving bordeaux. Moreover, it developed more extensively in trees sprayed with limesulfur November 11 than in those sprayed November 25 and December 16. Apparently, therefore, lime-sulfur lost much of its protective value before the end of the season, whereas bordeaux retained its protective qualities to a marked degree.

One and Two Treatments of Bordeaux. Reductions in the incidence of leaf spot by one and two treatments of bordeaux given during the fall and winter months are presented in table 2. 
In the 1943-44 season, the first spray, which was not applied until January 6 , reduced infection 71 per cent. A second spray applied February 5 , improved control to some extent in trees which had been sprayed January 6, though alone the February treatment was relatively ineffective.

In 1944-45 single applications on December 18, January 12, and February 20 reduced the incidence of the disease 75,67 , and 55 per cent, respectively. Programs consisting of two sprays, on the other hand, were somewhat more effective where the first treatment was given December 18. Thus, the December 18 and January 13 program reduced infection 91 per cent, the December 18 and February 20 program 84 per cent, but the January 12 and February 20 program was no better than the single-treatment program of January 12.

In the 1945-46 season the single-spray programs of November 13 and December 12 reduced leaf spot 95 and 98 per cent, respectively, but the February 20 program was much less effective. Little additional control was obtained by spraying twice, on November 13 and January 22, or on December 12 and January 22, or three times on November 13, December 12, and January 22.

The improved control from the single spraying on December 12, 1945, as compared with that on December 18, 1944, may have been due partly to the higher concentration of bordeaux employed (10-10-100 in 1945 and 8-8-100 in 1944). On the other hand, more infection may have occurred before the 1944 spraying date than before the 1945 one. The results for these two seasons seem to indicate that proper timing was more important than repeated treatments. Early infection in the autumn of 1947 was doubtless responsible for the poor results secured with bordeaux and with lime-sulfur in the 1947-48 season.

Persistence of Fungicide Fffects. In certain plots given one treatment a year for three years, leaf spot was reduced 73 per cent in 1944,79 per cent in 1945, and 99 per cent in 1946. These results are not conclusive, but seem to indicate that control increases as treatment is repeated year after year.

Data of a different nature, however, reveal that spray treatment during one infection season significantly reduced the incidence of leaf spot the following season. For example, at Strathmore, Tulare County, poor control of leaf spot was obtained in Manzanillo trees receiving bordeaux in February, 1945, and in Mission trees receiving bordeaux in February and May, 1945. The following year (1946), however, though these trees received no further spray, leaf spot infection in the Manzanillo variety was 87 per cent less than that in unsprayed trees and in the Mission variety 97 per cent less. At Fair Oaks in 1945, trees sprayed with the bordeaux-borax mixture on January 12 and February 20, 1945, developed 74 per cent less leaf spot than unsprayed trees. The following year, though no further treatment was given, these trees developed 93 per cent less disease than unsprayed trees.

Further evidence on this point was secured in the spring of 1948. The November 26, 1946, treatments of lime-sulfur and bordeaux, it will be recalled, gave excellent control of leaf spot during the 1946-47 season, whereas the January 21, 1947, treatments were much less effective. On November 11, 1947, some of the 1946-47 plots were again sprayed, others were not. Comparisons of the incidence of leaf spot in these plots for the 1947-48 season appear in table 3. The November 11 lime-sulfur treatment, as noted earlier, proved less 
effective in the 1947-48 season than November treatments in other years, apparently because infection occurred before the treatment was given: leaf spot was only 76 per cent less in trees sprayed on this date than in unsprayed trees. In trees sprayed with lime-sulfur both November 26, 1946, and November 11, 1947, however, the disease was 99 per cent less. In trees sprayed with lime-sulfur November 26, 1946, but given no further spraying, the amount of leaf spot in 1948 was 90 per cent less than in unsprayed trees. On the other hand, the reduction of leaf spot accompanying the January 21, 1947, limesulfur spraying was only 27 per cent. Much the same results were secured with the bordeaux treatments. The November 26, 1946, treatment with this

TABLE 3

EFFECT OF SPRAYING IN THE 1946-47 SEASON ON THE INCIDENCE OF THE DISEASE IN THE 1947-48 SEASON

\begin{tabular}{|c|c|c|c|c|}
\hline \multirow{2}{*}{ Material and concentration } & \multicolumn{2}{|c|}{ Dates of applying spray } & \multirow{2}{*}{$\begin{array}{l}\text { Average } \\
\text { number } \\
\text { lesions on } \\
100 \text { leaves } \\
\text { in } 1948 \dagger\end{array}$} & \multirow{2}{*}{$\begin{array}{l}\text { Per cent } \\
\text { reduction in } \\
\text { the incidence } \\
\text { of leaf spot } \\
\text { in } 1948\end{array}$} \\
\hline & $\begin{array}{l}1946-47 \\
\text { season* }\end{array}$ & $\begin{array}{c}1947-48 \\
\text { season }\end{array}$ & & \\
\hline$\ldots \ldots \ldots \ldots \ldots \ldots$ & $\ldots \ldots$ & & 215 & $\ldots$ \\
\hline Lime-sulfur, 3 per cent. . . . . . & Nov. 26,1946 & $\ldots \ldots$ & 21 & 90 \\
\hline Lime-sulfur, 3 per cent. . & Jan. 21, 1947 & & 156 & 27 \\
\hline Bordeaux, $10-10-100$ & Nov. 26, 1946 & & 29 & 86 \\
\hline Bordeaux, $10-10-100$ & Jan. 21, 1947 & & 80 & 63 \\
\hline 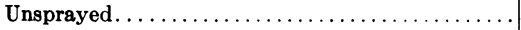 & $\ldots \ldots \ldots \ldots$ & & 272 & . \\
\hline
\end{tabular}

* The November 26 treatments of lime-sulfur and bordeaux were highly effective in the 1946-47 season; the January 21 treatments relatively ineffective (table 1).

$\dagger$ Results taken in March, 1948.

fungicide reduced leaf spot in the 1947-48 season 86 per cent, whereas the January 21,1947 , treatment was somewhat less effective (63 per cent).

Spraying in one season might influence the amount of disease development the following season in either of two ways: (1) because the inoculum source in the trees is reduced, and (2) because effective fungicide residues remain on the leaves until the next infection season. Though the data at hand do not warrant definite conclusions on these points, the inoculum level in the trees apparently played a role in determining the amount of disease developing in 1948 , for leaf spot was much lower in plots where the disease was effectively controlled the previous season than in plots where control was poor. The effect of the spray residue, however, should not be discounted, for the January 21, 1947, treatment of bordeaux appeared to influence disease development in 1948 considerably more than the parallel lime-sulfur treatment; and bordeaux residues are generally regarded as retaining their effectiveness for longer periods than lime-sulfur residues.

Discussion. Judging from the results of these and other studies, moderate temperatures and abundant moisture in the form of rain or fogs are favorable to the activity of Cycloconium oleaginum. So far as its sporulation and its infection of leaves are concerned, the fungus is inactive in central California during the warm, dry summer. In the autumn, mycelium of the fungus at the 
periphery of lesions extends laterally into the surrounding leaf tissue and produces conidia on the surface of the newly involved areas. A supply of inoculum is then available. Infection of leaves occurs during favorable periods of wet weather.

Under such circumstances the successful prevention of infection by protective fungicides largely depends upon timely applications of the spray. Unsatisfactory control will be obtained if the treatments with such materials as lime-sulfur and bordeaux are not given before protracted rains begin in autumn or early winter. Rains of sufficient duration to cause abundant infection, of course, may occur earlier in some seasons than in others. For example, in 1946 no rains of consequence occurred before the November 26 spraying, whereas in 1947 there was sufficient rainfall before the November 11 spraying to initiate infection; hence reduction of infection from the November spraying was 99 per cent in 1946-47, and only 36 per cent in 1947-48.

Apparently, therefore, in seasons such as 1947-48, prevention of the earliest major attack by the fungus requires a fungicidal treatment in October, probably as early as the middle of the month. A treatment at this time would conflict with the harvesting of pickling olives and deposit an undesirable residue on fruit, which is to be picked within a few days. November spraying, which gave satisfactory results in 1945-46 and 1946-47, would not often conflict with harvesting of pickling fruit. Fruit destined for oil or Greek processing would still be on the tree in November but since such fruit is not picked until December or January, some of the spray residue at least would be washed away by rains. Delaying the application of spray until all fruit is harvested, on the other hand, though avoiding residues on the fruit, is not effective against the disease. An alternative which seems to offer some promise, is that of early fall spraying for a year or two, or until the leaf spot is brought under control. Postharvest spraying might then hold the disease in check. The efficacy of such a program, of course, remains to be demonstrated. 


\section{LITERATURE CITED}

Anagnostopoulos, P. T.

1937. The Cycloconium of the olive in Greece. [Translated title.] Hort. Res., Athens, 1937:357-67. Reviewed in: Rev. Appl. Mycol. 17:405; 1938.

ANONYMOUS.

1932. Legislative and administrative measures in Spain. Internatl. Bul. Pl. Prot. 6:164-67. Reviewed in: Rev. Appl. Mycol. 12:127; 1933.

1941. Principales enfermedades parasitarias que fueron objecto de consulto en el segundo semestre (Julio-Diciembre) de 1941. Sanid. Veg. Santiago, Bol. 1:52-55.

BERNÈs, J.

1923. Les parasites de l'olivier au Congrès oléicola de Nice. Prog. Agr. et Vitic. $80: 518-24$.

BIoletTi, F. T., and Geo. E. Colby.

1899. Olives. California Agr. Exp. Sta. Bul. 123:1-34.

BOYER, G.

1891. Recherches sur les maladies de l'olivier: le Cycloconium oleaginum. Montpellier École Natl. d'Agr. Ann. 6:248-54.

BRIZI, U.

1894. Concerning Cycloconium oleaginum. [Translated title.] Staz. Sper. Agr. Italy 26: 227-231. Reviewed in: U.S. Off. Expt. Stas., Expt. Sta. Rec. 6:62; 1894-95.

1899. Bird's-eye of olives. [Translated title.] Staz. Sper. Agr. Italy 32:329-98. Reviewed in: U.S. Off. Expt. Stas., Expt. Sta. Rec. 11:554; 1899-1900.

Canonaco, A.

1936. Contributo alla flora micologica dell'A.O.I. I. Micromiceti dell'Eritrea. II. Ustilaginee. Boll. Giard. Bot. Palermo 14:1-28. Reviewed in: Rev. Appl. Mycol. 16: $279 ; 1937$.

Castagne, L.

1845. Catalogue des plantes qui croissent naturallement aux environs des Marseilles. p. 220. Reviewed by Boyer (1891).

Fов̈х, E.

1924. Quelques maladies crytogamiques de l'olivier. VI Cong. Internatl. d'Oléiculture. Compt. Rend. des Trav. [Nice] 1923:179-209.

Giulivo, G.

1927. Il vaiolo dell'olivo. Istria Agr. $7: 229-30$.

GoRTER, G. J. M. A.

1943. A leaf spot disease of the olive. Farming in So. Africa 18: 795-98.

GuozDEnovic, F.

1901. Report of the Agricultural Chemical Experiment Station in Spalato. [Translated title.] Oestrr. Landw. Versuchsw. Ztsch. 4:254-72. Reviewed in: U.S. Off. Expt. Stas., Expt. Sta. Rec. 13:661; 1901-02.

HANSEN, H. N.

1938. The dual phenomenon in imperfect fungi. Mycologia 30:442-55.

HANSEN, H. N., and W. C. SNYDER.

1943. The dual phenomenon and sex in Hypomyces solani f. cucurbitae. Amer. Jour. Bot. $30: 419-22$.

Hayne, ARThur P.

1893. Olives and olive oils. California Agr. Exp. Sta. Rept. 1892-93:279-322.

HoRNE, W. T.

1917. Some diseases of the olive in California. Olive Jour. 1 (February) : 4, 10.

Horne, W. T., E. O. Essia, and W. B. Herms.

1923. Plant disease and pest control. California Agr. Exp. Sta. Cir. 265:1-96.

MARINANGELI, L.

1928. Note di olivicoltura. Di due parassiti dell'olivo contro i quali occore subitro agire. Il Coltivatore 74:379-82. Reviewed in : Rev. Appl. Mycol. 7:653; 1928.

MIÈGE, E.

1922. Observations sur quelques maladies des plantes cultivées au Maroc en 1921. Soc. de Path. Vég. France Bul. 9:108. 
MONIZ DA MAIA, R.

1924. Contribuição para o estudo da importância fitopatológica do Schizophyllum alneum (L.) Schroet., em Portugal. Agron. Rev. (Lisbon) 4th Ser. 1:20-22.

NATtrass, R. M.

1935. Diseases of the olive. Cyprus Agr. Jour. 30:55-57.

Navarro, L., and E. Noriega.

1909. Diseases of the olive. [Translated title.] Prog. Agr. y Pecuario 15:31-33. Reviewed in: U.S. Off. Expt. Stas., Expt. Sta. Rec. $20: 1140 ; 1908-09$.

Nicolas, G., and Mlle. AgGÉry.

1928. Un Cycloconium parasite de Phillyrea angustifolia. Soc. Myc. de France Bul. 44: $301-3$.

Petri, D. L.

1913. Studi sulle malattie dell'olivo. III. Alcune ricerche sulla biologia del Cycloconium oleaginum Cast. [Roma] R. Staz. di Patol. Veg. Mem. p. 3-136. Tipografia Nazionale di G. Bertero E. C.

ToBler, O., and U. RosSi-FerRini.

1906. The use of bordeaux mixture for the control of Cycloconium on the olive. [Translated title.] R. Accad. Econ. Agr. dei Georg. Firenze. Atti (Series 3) 5:327-37. Reviewed in: U.S. Off. Expt. Stas., Expt. Sta. Ree. $18: 451 ; 1906-07$.

VenNuCCINI, V.

1898. A leaf disease of olives. [Translated title.] Ent. Agr. e Patol. Veg. Bol. 5:85-87. Reviewed in: U.S. Off. Expt. Stas., Expt. Sta. Rec. 11:59; 1899-1900.

WiLson, E. E.

1946. The peacock leaf spot of olive trees. California Olive Indus. News. 1:4.

ZaCharewicz, E.

1903a. La fumagine de l'olives et le Cycloconium oleaginum. Prog. Agr. et Vitic. (Ed. l'Est) 24:110-13. Reviewed in: U.S. Off. Expt. Stas., Expt. Sta. Rec. 14:881; 1902-03.

1903b. The sooty mold of the olive. [Translated title.] Bul. Agr. de Algérie et Tunisie Bul. 9:179-86. Reviewed in: U.S. Off. Expt. Stas., Expt. Sta. Rec. 15:270; 1903-04. 
The journal Hilgardia is published at irregular intervals, in volumes of about 600 pages. The number of issues per volume varies.

Subscriptions are not sold. The periodical is sent as published only to libraries, or to institutions in foreign countries having publications to offer in exchange.

You may obtain a single copy of any issue free, as long as the supply lasts; please request by volume and issue number from:

\section{Publications Office \\ College of Agriculture \\ Berkeley 4, California}

The limit to nonresidents of California is 10 separate issues on a single order. A list of the issues still available will be sent on request.

In order that the information in our publications may be more intelligible it is sometimes necessary to use trade names of products or equipment rather than complicated descriptive or chemical identifications. In so doing it is unavoidable in some cases that similar products which are on the market under other trade names may not be cited. No endorsement of named products is intended nor is criticism implied of similar products which are not mentioned. 


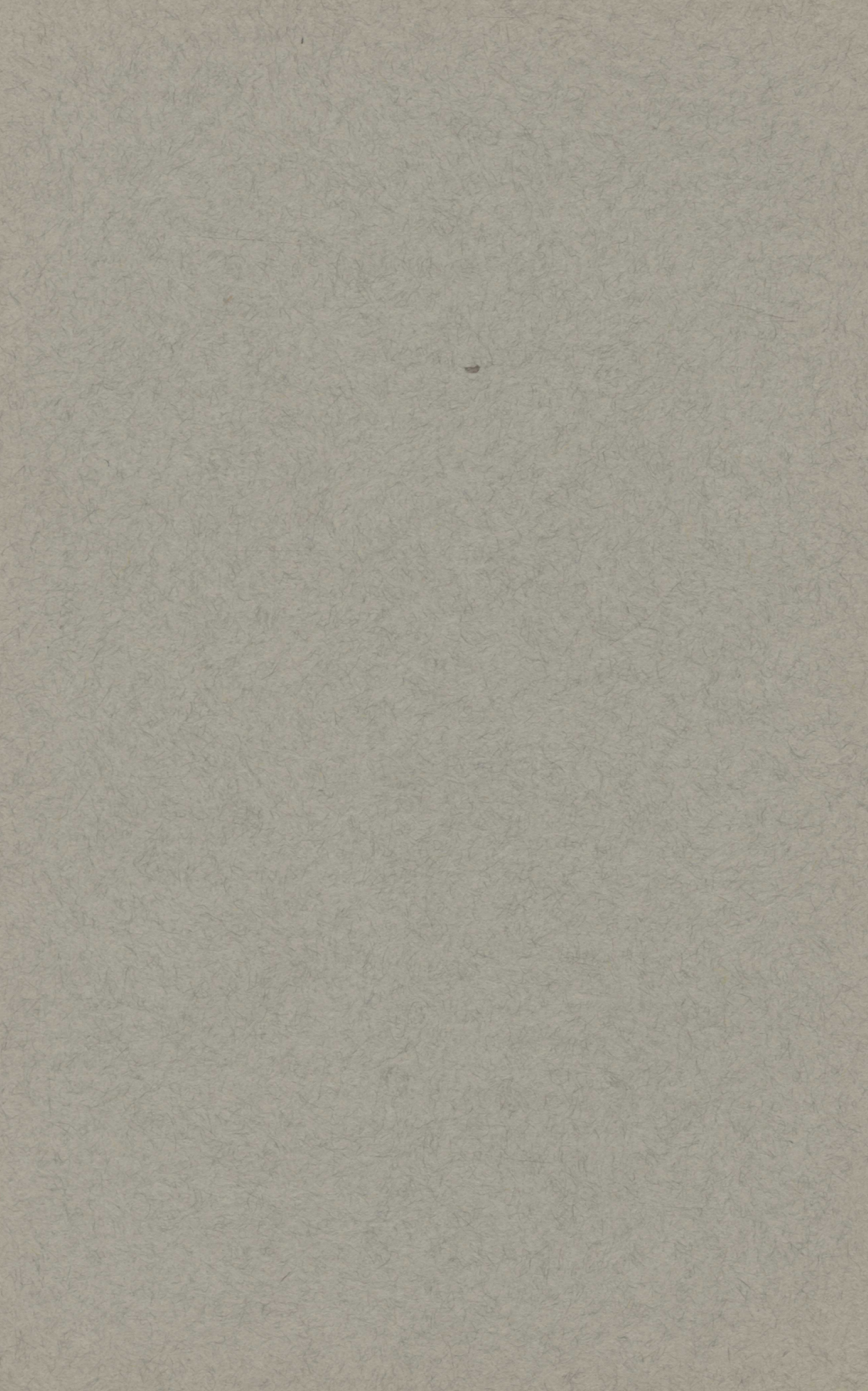

